\title{
Epstein-Barr Virus in the Development of Colorectal Cancer (Review)
}

DOI: $10.17691 / \mathrm{stm} 2021.13 .4 .09$

Received December 4,2020

N.A. Oleynikova, MD, PhD, Researcher, Department of Clinical Pathology';

N.V. Danilova, MD, PhD, Senior Researcher, Department of Clinical Pathology";

M.O. Grimuta, Student';

P.G. Malkov, MD, DSc, Head of the Department of Clinical Pathology ${ }^{1}$

Medical Scientific and Educational Center, Lomonosov Moscow State University, 27/10 Lomonosov Prospect,

Moscow, 119192, Russia;

21.M. Sechenov First Moscow State Medical University (Sechenov University), 8/2 Trubetskaya St., Moscow, 119991, Russia

The study of the influence of the Epstein-Barr virus (EBV) on the development of colorectal cancer is of current interest, particularly in light of the active discussion of the participation of this virus in the carcinogenesis of stomach cancer. In this review, aimed at a fundamental understanding of the processes associated with the impact of EBV on the human body, attention is paid to the issues of the life cycle of the virus, its phases (latent and lytic), as well as proteins that may be detected in each of the phases. The papers reporting on the role of EBV in the development of colorectal cancer have been analyzed. A summary table indicating the population under study, the number of samples, the method, and the result obtained is provided. Given that the primary cells affected by EBV are lymphocytes, it is logical to assume the involvement of this virus in the development of inflammatory bowel diseases. The review cites studies which confirm the presence of virus DNA in tissues in the inflammatory diseases of the colon, including microscopic and ulcerative colitis. To confirm the direct impact of EBV on the development of colorectal cancer, large studies with applying various methods for detecting the virus and the mandatory description of its localization are required. Besides, it is necessary to correlate these data with the clinical and morphological characteristics of EBV.

Key words: Epstein-Barr virus; colorectal cancer; the cycle of the virus; carcinogenesis; inflammatory diseases of the colon.

How to cite: Oleynikova N.A., Danilova N.V., Grimuta M.O., Malkov P.G. Epstein-Barr virus in the development of colorectal cancer (review). Sovremennye tehnologii v medicine 2021; 13(4): 82, https://doi.org/10.17691/stm2021.13.4.09

This is an open access article under the CC BY 4.0 license (https://creativecommons.org/licenses/by/4.0/).

\section{Introduction}

The Epstein-Barr virus (EBV) is the first detected and one of the most common oncoviruses which accounts for approximately $10-15 \%$ of all malignant neoplasms. It belongs to the group of gamma viruses and is ubiquitous in the adult population. The virus infects more than $90 \%$ of the world's population by the age of 35 , most being asymptomatic. The main pathway for its transmission is through the saliva [1].

The penetration of the virus into B lymphocytes located in the submucous lymphoid tissue (for example, in the tonsils) [2,3] occurs when the EBV surface protein gp350 interacts with the CD21 receptor and HLA class II molecules. The way the virus "crosses" the mucous epithelial integument remains unclear, however, it has been established that, in addition to $B$ cells, it is found in the epithelial cells of EBV-associated carcinomas, as well as in other hematopoietic cells ( $T$ cells, granulocytes, and natural killer cells) $[4,5]$.

The EBV causes infectious mononucleosis, some lymphoproliferative diseases (Burkitt's Iymphoma,
Hodgkin's lymphoma, T/NK cell lymphomas), as well as post-transplant lymphoproliferative conditions, promotes the development of epithelial neoplasms, including nasopharyngeal carcinomas and gastric carcinomas [6-8]. There are data on the expression of the virus in carcinomas of the breast, prostate, mouth, cervix, and salivary glands [9-14].

\section{EBV replication}

The EBV genome consists of double-stranded DNA, which is approximately 172,000 bp in length [2]. It encodes viral oncogenes, such as EBV-encoded nuclear antigens (Epstein-Barr nuclear antigen, EBNA [15]) and latent membrane proteins (LMP) [16]. The main function of these proteins is to help maintaining genome replication by evading natural immune control mechanisms. Moreover, the corresponding EBNA and $L M P$ genes have been found to play an important role as oncogenes in infected cells $[2,15,17]$.

The EBV can replicate in two ways: by infecting $B$ cells (latent form) and by lytic production of the virion

Corresponding author: Nina A. Oleynikova, e-mail: noleynikova@mc.msu.ru 
(lytic form) [3, 18]. In its latent form, the viral DNA enclosed in a round plasmid behaves like the host chromosomal DNA and encodes viral genes, including six nuclear antigens (EBNA1, -2, -3A, -3B, -3C, and $-\mathrm{LP}$ ), three latent membrane proteins (LMP1, -2A, and $-2 \mathrm{~B}$ ), two small non-coding RNAs (EBER1 and -2), 44 miRNAs, and a BamHI-A transcript [19-21]. This leads to activation, proliferation of cells, and their resistance to "dying". In vitro in B cells, the virus persists in a latent form with the expression of non-coding RNAs from viral DNA, thereby transforming B lymphocytes into "immortal" proliferating lymphoblastoid cell lines [22]. All the above-mentioned products have been found in lymphoblastoid cell lines, naive tonsillar B cells of healthy viral carriers, and almost all $B$ cells of patients with infectious mononucleosis [3, 23-25].

After crossing the mucous membrane of the epithelium, the salivary virus infects the $B$ cells of the lymphoid tissue of the tonsils, which leads to EBNA2-dependent proliferation of the infected cells. Infected B cells can differentiate into latency 0 immediately after infection (EBV persists in circulating memory $B$ cells without expressing viral particles). Transformation to latency III, during which EBNA1, EBNA2, EBNA3A-3C, EBNA-LP, LMP1, and LMP2 are expressed, is an alternative. After activation of latency III, B lymphocytes enter the germinal center of the lymphoid follicle. At this stage (called latency lla), only three proteins (EBNA1, LMP1, and LMP2) are found in B lymphocytes. Latency lla can become latency 0 , at which viral proteins are not produced. During cell division, which is in latency 0 , latency I sets in, during which EBNA1 is present [26]. This phase is observed in healthy carriers of the virus and corresponds to a precancerous one [3]. Thus, four types of latent gene expression have been described for EBV, three of which (latency I, II, and III) are observed in malignant neoplasms associated with EBV [27]. According to some reports [4], latency I is most often associated with Burkitt's lymphoma; latency II with Hodgkin's lymphoma, T cell non-Hodgkin's lymphomas, and nasopharyngeal carcinoma (NPC), and latency III predominantly occurs in immunocompromised patients (e.g., post-transplant and AIDS-related lymphoproliferative disorders). According to the results of other studies [3], latency II is associated with diffuse large B cell lymphoma (DLBCL), and latency III — with Burkitt's lymphoma and Hodgkin's lymphoma (Figure 1).

In the lytic form, the EBV genome is sharply amplified (up to 1000 times) by the viral replication mechanism and selectively replicates the virion components (viral DNA - genomes and proteins). This process takes place in replicating compartments within the nucleus: the lytic program stops the cell cycle and significantly affects cellular processes. The lytic form of EBV infection is considered as a mechanism by which the virus induces neoplastic transformation into EBV-associated malignant neoplasms (carcinomas and lymphomas) [28]. This mechanism involves the transcription factors BZLF1 and BLIMP1, the latter of which is required for

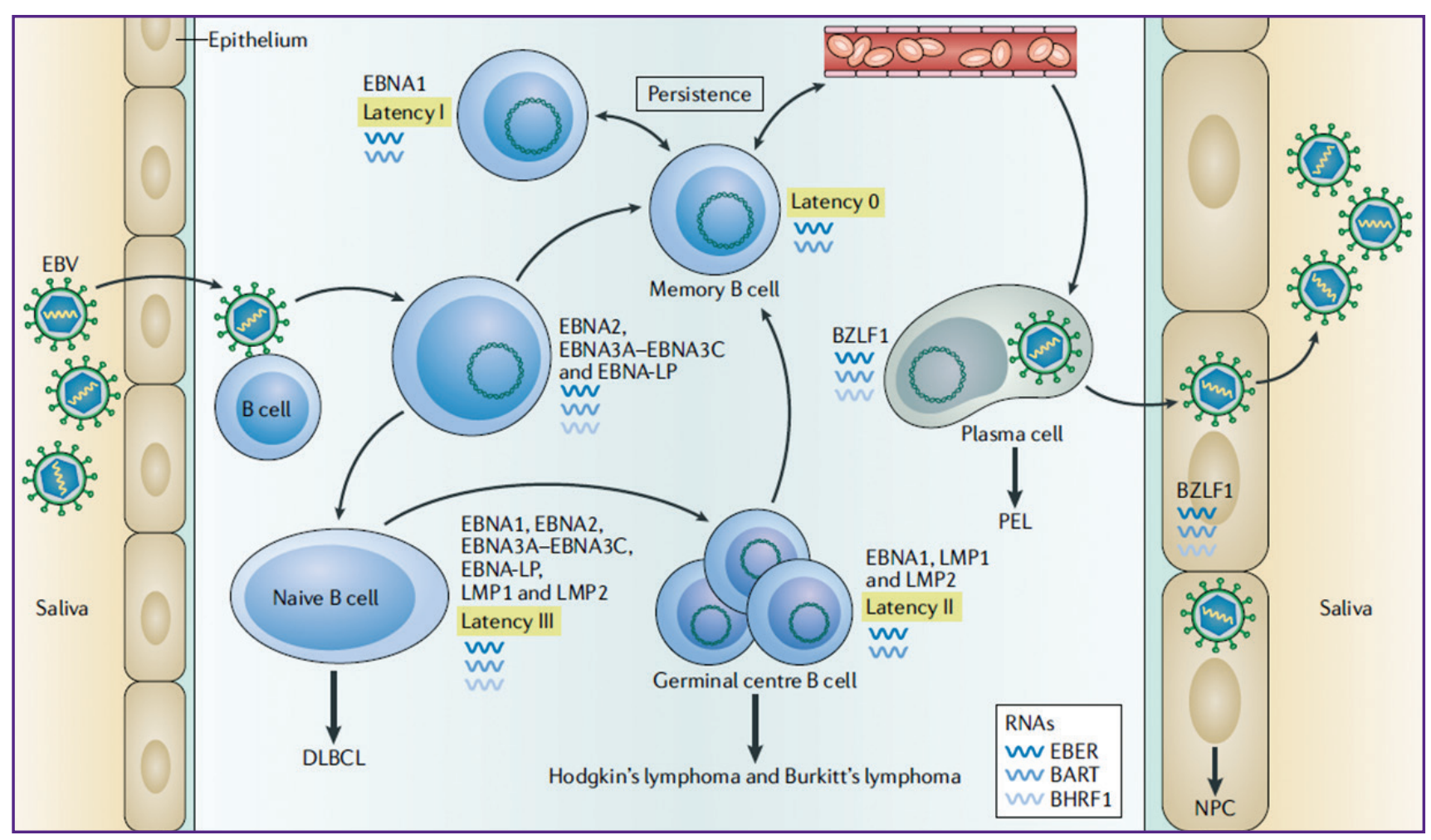

Figure 1. Model of latent infection of the Epstein-Barr virus. Given under [3]

Here: $\mathrm{PEL}$ — primary effusion lymphoma 


\section{REVIEWS}

uncontrolled replication in epithelial cells (for example, in hairy leukoplakia of the oral cavity) [29]. In asymptomatic persistence of the virus, the lytic products of EBV, which subsequently stimulate the differentiation of B cells into plasma, are observed exclusively in plasma cells [3].

As already noted, the functions of proteins produced in the latent EBV form are different. Thus, EBNA1 is required for the initiation of viral genome replication during latent infection prior to the onset of mitosis. Then, this protein fixes the viral episome to the host chromatin during cell division in order to correctly distribute 10-40 viral particles from the mother $B$ cell to the daughter one [30]. EBNA2 induces transcription of the cellular MYC oncogene and decreases lytic EBV replication through the induction of TET2 expression. EBNA-LP cooperates with EBNA2 to express viral oncogenes, including LMP1. EBNA3A and EBNA3C prevent the cell transition to lytic replication by suppressing BLIMP1 expression. On the contrary, EBNA3B provides sufficient tissue infiltration of immune cells around the EBV-transformed $B$ cells to restrict the latter to a level where most asymptomatic EBV individuals do not develop lymphoma. LMP1 is a pro-proliferative and antiapoptotic protein, and LMP2 provides a strong surface signal for B cell survival [3].

\section{EBV in the development of colorectal cancer}

The similar structure and common histo- and embryogenesis of the stomach and other organs of the digestive tract suggest a possible role of EBV in the development of epithelial tumors, including colorectal cancer (CRC). The available literature contains less than 30 studies on the search for EBV in CRC samples (Table 1). Most of them were performed on small samples and have limitations associated with the research method. So, PCR involves the isolation of genetic material from paraffin blocks, and the obtained finding directly depends on the quality and completeness of the isolation of the material. The immunohistochemical method (IHC) for the detection of EBNA and LMP proteins (LMP proteins are cytoplasmic/membrane proteins, and EBNA proteins are nuclear ones) also has limitations which lead to a large number of falsepositive results [31]. The described difficulties are also characteristic for the works that study the influence of EBV on the development of gastric cancer, though, in quite a bigger number [32, 33].

Most of the modern studies have succeeded in EBV detection in CRC tissue samples by various methods, while almost all the results of twenty years ago were

Table 1

Epstein-Barr virus detection studies in colorectal cancer samples

\begin{tabular}{|c|c|c|c|c|c|}
\hline Author, year & Population & Sample size (n) & EBV status $(\%)$ & Detection method & References \\
\hline Malki et al., 2020 & North America & 102 & Detected -20 & PCR & [34] \\
\hline Gupta et al., 2020 & Bosnia & 106 & Detected -25 & PCR and IHC & {$[35]$} \\
\hline Sarvari et al., 2018 & Iran & 210 & Detected -1.4 & PCR & {$[36]$} \\
\hline Al-Antary et al., 2017 & Syria & 102 & Detected -36 & PCR and IHC & {$[37]$} \\
\hline Mehrabani-Khasraghi et al., 2016 & Iran & 35 & Not detected & PCR & {$[38]$} \\
\hline Tafvizi et al., 2015 & Iran & 50 & Detected - 38 & PCR & {$[39]$} \\
\hline Sole et al., 2015 & Chile & 37 & Detected - 46 & PCR & [40] \\
\hline Guan et al., 2015 & China & $\begin{array}{l}54,675 \\
\text { samples }\end{array}$ & Detected relationship & Microarray analysis & [41] \\
\hline Fiorina et al., 2014 & Italy & 44 & Not detected & PCR in real time and IHC & [42] \\
\hline Salyakina and Tsinoremas, 2013 & North America & 117 & Detected -21 & PCR, sequencing & [43] \\
\hline Khoury et al., 2013 & North America & 204 & Not detected & Sequencing & [44] \\
\hline Delaney and Chetty, 2012 & Great Britain & 1 & Not detected & IGC & [45] \\
\hline Karpinski et al., 2011 & Poland & 186 & Detected - 19 & PCR & {$[46]$} \\
\hline Chang et al., 2011 & Taiwan & 1 & Detected & PCR & [47] \\
\hline Park et al., 2010 & South Korea & 72 & Detected -30.6 & IHC and hybridization in situ & [48] \\
\hline Nishigami et al., 2010 & Japan & 1 & Not detected & IGC & [49] \\
\hline Militello et al., 2009 & Italy & 100 & $\begin{array}{l}\text { Detected in the material from } \\
\text { paraffin blocks }-2.8 \text {; in the freshly } \\
\text { frozen material }-39.3\end{array}$ & $\begin{array}{l}\text { PCR in real-time } \\
\text { and sequencing }\end{array}$ & [50] \\
\hline Song et al., 2006 & China & 90 & Detected - 30 & IHC and hybridization in situ & [51] \\
\hline Wong et al., 2003 & Scotland & 26 & Not detected & Hybridization in situ & [52] \\
\hline Grinstein et al., 2002 & Argentina & 19 & Detected - 5 & Hybridization in situ & [53] \\
\hline
\end{tabular}




\begin{tabular}{|c|c|c|c|c|c|}
\hline Author, year & Population & Sample size (n) & EBV status (\%) & Detection method & References \\
\hline Kon et al., 2001 & Japan & 1 & Detected & PCR & [54] \\
\hline Kijima et al., 2001 & Japan & 102 & Not detected & Hybridization in situ & [55] \\
\hline Cho et al., 2001 & South Korea & 274 & Not detected & Hybridization in situ & [56] \\
\hline Samaha et al., 1998 & North America & 1 & $\begin{array}{l}\text { Not detected with } \mathrm{IHC} \text {, detected } \\
\text { with PCR }\end{array}$ & $\mathrm{IHC}$ and $\mathrm{PCR}$ & {$[57]$} \\
\hline Vilor et al., 1995 & Australia & 1 & $\begin{array}{l}\text { Not detected in tumor cells, } \\
\text { detected in intact tissue }\end{array}$ & Hybridization in situ & [58] \\
\hline Yuen et al., 1994 & China & 36 & Not detected & Hybridization in situ & [59] \\
\hline Boguszakova et al., 1988 & Czechoslovakia & 13 & Not detected & PCR & [60] \\
\hline Nonoyama et al., 1974 & North America & 10 & Detected - 10 & $\begin{array}{l}\text { Kinetics of DNA-DNA } \\
\text { reassociation }\end{array}$ & [61] \\
\hline
\end{tabular}

negative $[55,56,59,60]$. From recent studies, a practically negative result was obtained by Sarvari et al. [36]: EBV was identified by PCR in only one sample out of 210 paraffin blocks (70 adenocarcinomas, 70 adenomas, and 70 controls). The low number of positive samples in colorectal cancer tissue is likely to be associated not with the absence of this virus in a specific tumor, but with the quality of isolation of genetic material from paraffin blocks. Thus, in the study by Tafvizi et al. [39], aimed at detecting virus DNA in CRC tissue samples with the PCR method, different results were obtained. Fragments of virus DNA were found in $38 \%$ $(19 / 50)$ of colorectal cancer cases and in 50\% (25/50) of cases in the group with non-malignant colon lesions (in $1 / 12$ of adenomas and $24 / 38$ biopsies of non-neoplastic intestinal lesions). The virus was most often found in moderately differentiated adenocarcinomas $(p>0.05)$. It cannot be ruled out that this result is associated with a large spread of G2 tumors and not supported by specific molecular features characteristic precisely for G2 tumors. The authors found a statistically significant association between viral persistence and the stage of the disease: $42.1 \%(8 / 17)$ of CRC samples at stage I, $36.9 \%(7 / 27)$ at stage II, $15.8 \%(3 / 4)$ - at stage III, and $5.2 \%(1 / 2)$ - at stage IV were positive for EBV infection.

Similar results were obtained by Fiorina et al. [42]. When studying paraffin blocks using PCR, the virus was reported to be detected in 52\% (23/44) of cases of colorectal cancer. It is noteworthy, that the edges of the resection of the patients' surgical material were used for the virus isolation, and not the intact mucous membrane of the colon. It was found that EBV was more often observed in tumors with pronounced lymphocytic infiltration $(p=0.06)$. In situ hybridization (EBER1 and -2 RNA) helped to demonstrate that the virus is located in different zones of lymphoid infiltrates, and not in tumor cells. Using IHC, the EBNA1 nuclear protein was not detected in any neoplastic cell, despite the fact that it should be expressed in both the latent and lytic phases. The IHC study did not detect the LMP1 membrane protein involved in activation either, despite the fact that the lytic cycle was confirmed by the immediate-early protein BZLF1 expressed during lytic replication (see Figure 1).

All the studies we have reviewed show virus tropism particularly to lymphoid infiltrates and are very important in understanding the molecular mechanisms of EBV in $\mathrm{CRC}$, despite the fact that the authors have not noted the relationship with clinical and morphological parameters.

A study by Mehrabani-Khasraghi et al. [38] was carried out on the freshly frozen material obtained from 35 patients (15 cases of colorectal cancer and 20 cases of colon polyps): fragments of the neoplasm itself and intact mucous membrane were studied. There was no statistically significant difference between the presence of EBV and neoplasm. In some cases, virus DNA was detected in pathological areas $(9 / 15(60 \%)$ cases in the CRC group and $7 / 20(35 \%)$ cases in the polyp group) and in the adjacent intact mucous membrane surrounding the tumor $(4 / 15(26.7 \%)$ cases in the CRC group and $11 / 20$ (55\%) cases in the polyp group).

The range of EBV-positive patients in various studies is quite large. So, Karpinski et al. [46], using PCR, detected the virus in $19 \%$ of cases of colorectal cancer, Sole et al. [40] - in $27 \%$ of cases, Al-Antary et al. [37] - in $36.27 \%$ of cases. These data indicate a low relationship between $\mathrm{EBV}$ and $\mathrm{CRC}$, on the one hand, and the lack of knowledge of the prognostic role of the virus, on the other hand. Moreover, most works do not focus on the site where the virus was isolated from: from epithelial cells or the surrounding infiltrate. Given the widespread persistence of the virus and its latent form in $100 \%$ of the population, the question arises whether there is really an association between EBV and CRC.

A larger-scale study using the sequencing method was carried out by Salyakina and Tsinoremas [43]. Of 1009 cases of gastrointestinal tumors, represented by 9 different localizations, only gastric cancer and colorectal cancer showed a virus-positive result at the transcriptome level (TCGA). A statistically significant relationship between EBV and $\mathrm{CRC}$ was shown $(p=0.02)$, which indicates the potential oncogenicity of this virus. However, in a similar study [44], out of 204 
cases of CRC, not any EBV-positive result was identified.

In a number of works, two methods for detecting EBV were used: PCR and IHC. Thus, Gupta et al. [35] carried out a PCR study with two primers (EBNA1 and LMP1) on the material of 106 adenocarcinomas of the colon. It was found that in all cases with positive EBNA1 (15/106), LMP1 was also positive. However, 11 more cases were identified with isolated positive LMP1 $(n=26)$, which is rather curious, since EBNA1 is expressed in latency phases I, II, and III, while LMP1 is expressed only in latency phases II and III (see Figure 1). The IHC method was used to study 63 cases of colon adenocarcinoma (antibodies to LMP1). A positive response was detected only in $7 / 63$ cases, which is almost 2 times less compared to PCR. The result obtained by the authors makes one think about the specificity of the methods used, on the one hand, and the sensitivity of various markers, on the other hand. It should be noted that, according to IHC data, LMP1 expression was sometimes observed in the adjacent intact mucosa, and not only in the tumor itself; however, these data are not statistically confirmed.

Recent studies [62, 63] of stomach and colon cancer have focused on the identification of a new tumor suppressor gene ARID1A (at-rich interactive domain-containing $1 \mathrm{~A}$ protein), which encodes a large nuclear protein involved in the regulation of a number of processes, including cell differentiation and DNA repair. ARID1A mutates, particularly, in CRC. A metaanalysis conducted by Kim et al. [64], which included 6 studies and 3019 patients, confirmed the presence of EBV infection and loss of ARID1A protein expression in tumors with lower differentiation and high stage.

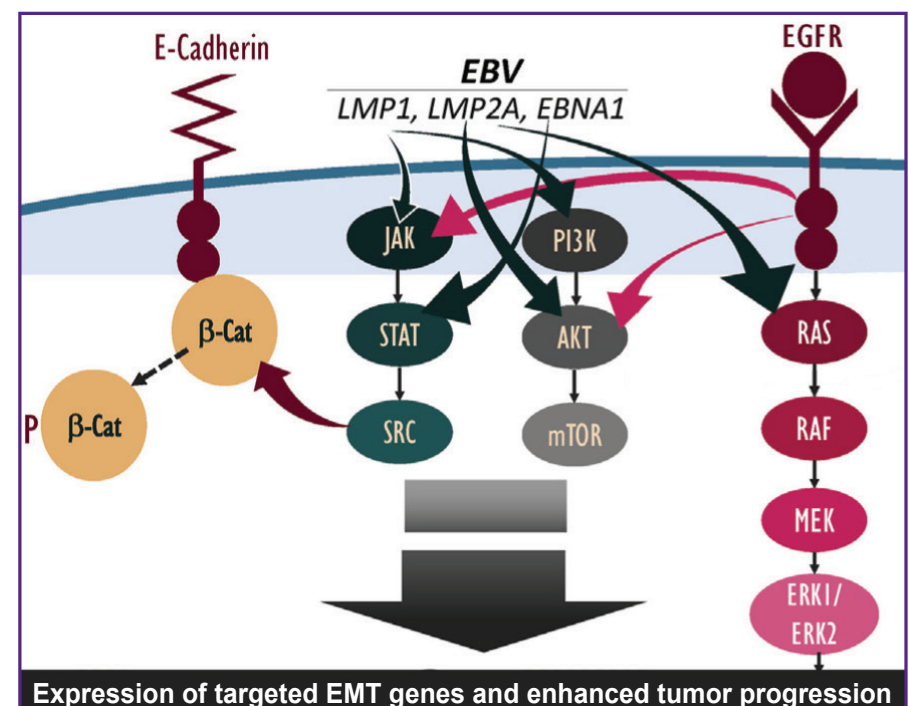

Figure 2. Influence of Epstein-Barr virus proteins on the development of epithelial-mesenchymal transition. Given under [8]

Here: EMT - epithelial-mesenchymal transition; JAK/STAT/ SRC, PI3K/AKT/mTOR, RAS/RAF/MEK/ERK1/ERK2 - signaling pathways; EGFR - a transmembrane glycoprotein receptor
The role of EBV in the initiation of the epithelial-mesenchymal transition

The epithelial-mesenchymal transition (EMT), first described in the early 1980s [65], is an important process in metastasis and tumor progression in general [66]. EMT leads to losing epithelial characteristics of cells, including transitional and apical-basal polarity. EMT can reorganize its cytoskeleton and undergo multiple biochemical alterations which enable the cell to migrate and invade surrounding tissues, acquiring a mesenchymal cell phenotype. This phenotype includes increased migratory ability, invasiveness, increased resistance to apoptosis, and increased production of extracellular matrix components $[67,68]$. In addition, it has been shown that the presence of inflammatory cytokines and hypoxia in the tumor microenvironment promotes the development of EMT [69].

Previously, the focus of EMT studies was limited to studying the mechanisms of direct acquisition of the mesenchymal phenotype by epithelial cells. In recent decades, evidence has been accumulated that oncoviruses and the proteins encoded by them have a significant effect on metastasis, on the EMT process in particular. The EBV oncoproteins (LMP1, LMP2A, and EBNA1) have been noted to enhance the development of carcinomas through the initiation of EMT [70]. LMP1 can reduce the expression of E-cadherin by inducing a transcriptional repression complex consisting of DNA methyltransferase (DNMT-1) and histone deacetylase and induce a switch from E-cadherin to N-cadherin [71]. LMP2A is another EBV oncoprotein. It is overexpressed in the vast majority of EBV-associated nasopharyngeal carcinomas. LMP2A has been established to enhance invasive/migratory capacity and induces alterations in EMF-like cellular biomarkers [72]. Besides, LMP2A is involved in the initiation of EMT, activating the 4EBP1-elF4E axis and, thereby, increasing the expression of metastatic tumor antigen-1. The latent EBV viral antigen, EBNA1, is a multifunctional viral protein that exhibits higher motility and migration potential, and also affects EMT markers [73]. There is evidence of the effect of miRNA on EMT and metastasis in various carcinomas, but the exact mechanisms of these processes are unknown [74]. The total effect of EBV proteins on EMT through various signaling pathways is shown in Figure 2.

$\mathrm{He}$ et al. [75] noted that miR-BART6-3p, which is EBV-encoded miRNA, inhibits EBVassociated migration and invasion of tumor cells of nasopharyngeal carcinoma and gastric carcinoma by reversing EMT. On the other hand, there is evidence of an increase in cadherin-6 in LMP1-positive tissues of nasopharyngeal carcinoma, which can induce EMT and promote metastasis of nasopharyngeal carcinoma [76]. Studies of miRNA in CRC are few. However, the data obtained by the sequencing method indicate a higher content of EBV miRNA in 
the tumor compared to the intact mucous membrane of the colon in the same patients $(p \leq 0.05)[77]$.

\section{EBV in inflammatory bowel diseases}

Since inflammatory bowel diseases are often regarded as precancerous conditions, and the nature of their occurrence does not always have a clearly described pathogen, it has been suggested that EBV influences the development of not only colon tumors but also inflammatory bowel diseases (Table 2) [78-81].

Thus, in a study by Nissen et al. [79] performed by in situ hybridization, EBER cells were detected in 28 out of 58 biopsy specimens (11/16 - Crohn's disease, $17 / 41$ - ulcerative colitis, and $0 / 1$ - indeterminate colitis). The relationship between the presence of EBV and atypical lymphoplasmacytic infiltrate was noted in the biopsy specimens $(p<0.001)$. However, it remains unclear what criteria were used to consider the infiltrate as atypical (the authors describe it as a disorganized infiltrate with large B lymphocytes). There is no information about where exactly the virus was found in the infiltrate or in the cells of the intestinal epithelium, either.

Earlier studies $[80,81]$ noted the presence of EBER exclusively in the lymphocytes of the lamina propria of the colonic mucosa, in lymphoid follicles, and even in the stroma of colon adenocarcinoma, but not in epithelial cells. It is noteworthy that the authors found EBV not only in samples with inflammatory disease of the colon but also in $44 \%$ of cases in the normal mucous membrane.

The study by Rizzo et al. [78] presents interest, in which the DNA of the virus was detected by PCR in $27 / 30(90.0 \%)$ cases of microscopic colitis, in $20 / 30$ $(66.7 \%)$ cases of ulcerative colitis, and none of the cases of irritable bowel syndrome. Using in situ hybridization, EBER positive cells were identified (mainly
B lymphocytes and histiocytes) in 18/30 (60.0\%) cases of microscopic colitis, in $3 / 30(10.0 \%)$ cases of ulcerative colitis. At the same time, the virus DNA was detected in none of the cases of irritable bowel syndrome $(n=30)$, which is not a true inflammatory process. The authors found that EBV infection is almost always present in patients with microscopic colitis, the pathogenesis of which has not yet been established.

The research data [78-81] confirming the presence of EBV in the inflamed colonic mucosa deserve special attention, since this may indicate its influence on the development of cancer by analogy with its influence on stomach cancer.

\section{Conclusion}

To date, there is no definite answer to the question about the direct effect of the EBV on the carcinogenesis of colorectal cancer. Until now, there is no generally accepted method for detecting the virus in tumor tissues of the colon, which leads to the incomparability of the results and the impossibility of forming a single basis. Most of the studies lack information about the location of the detected virus (epithelial cells or cells of lymphoid tissue), which is fundamentally important for assessing the stage of development of the EBV, on the one hand, and establishing its prognostic role, on the other hand. In addition, it is necessary to perform correlation analysis with clinical and morphological characteristics. Special attention should be given to the study of the role of the EBV in precancerous processes of the colon and inflammatory diseases since the virus has been identified in microscopic and ulcerative colitis.

Authors' contributions: N.A. Oleynikova worked out the conception of the review, wrote text, collected and analyzed scientific information; N.V. Danilova was

Table 2

Epstein-Barr virus status studies in inflammatory diseases of the colon

\begin{tabular}{|c|c|c|c|c|c|}
\hline Author, year & Population & Disease and sample size (n) & EBV status (\%) & Detection method & References \\
\hline Rizzo et al., 2017 & Italy & $\begin{array}{l}\text { Microscopic colitis }-30 \\
\text { Ulcerative colitis }-30 \\
\text { Irritable bowel syndrome }-30\end{array}$ & $\begin{array}{l}\text { Detected }-90 \\
\text { Detected }-66.7 \\
\text { Not detected }\end{array}$ & PCR and hybridization in situ & [78] \\
\hline Nissen et al., 2015 & Holland & $\begin{array}{l}\text { Ulcerative colitis }-40 \\
\text { Crohn's disease }-17 \\
\text { Unspecified colitis }-1\end{array}$ & $\begin{array}{l}\text { Detected }-57.5 \\
\text { Detected }-29.4 \\
\text { Not detected }\end{array}$ & Hybridization in situ & [79] \\
\hline Ryan et al., 2012 & USA & $\begin{array}{l}\text { Norm }-14 \\
\text { Crohn's disease }-9 \\
\text { Ulcerative colitis }-11\end{array}$ & $\begin{array}{l}\text { Detected }-44 \\
\text { Detected }-55 \\
\text { Detected }-64\end{array}$ & Hybridization in situ & [80] \\
\hline $\begin{array}{l}\text { Spieker and Herbst, } \\
2000\end{array}$ & Germany & $\begin{array}{l}\text { Ulcerative colitis }-25 \\
\text { Crohn's disease }-31 \\
\text { Collagen colitis }-8 \\
\text { Chronic appendicitis - } 21 \\
\text { Chronic diverticulitis - } 12 \\
\text { Intact mucosa }-19\end{array}$ & $\begin{array}{l}\text { Detected }-60 \\
\text { Detected }-80.6 \\
\text { Not detected } \\
\text { Detected }-14.3 \\
\text { Detected }-41.7 \\
\text { Detected }-47.4\end{array}$ & Hybridization in situ & [81] \\
\hline
\end{tabular}


involved in scientific text editing; M.O. Grimuta wrote a section "The role of EBV in the initiation of epithelialmesenchymal transition", collected scientific information; P.G. Malkov was responsible for scientific editing of the paper.

Research funding. This work was financially supported by the Russian Science Foundation (Grant No.20-75-00037 "The study of association with EpsteinBarr virus tumors of the stomach and colon, the study of the role of the persistence of viral antigens", within the Presidential Program "Initiative Research by Young Scientists").

Conflicts of interest. The authors declare no conflicts of interest related to the present study.

\section{References}

1. Fernandes Q., Gupta I., Vranic S., Al Moustafa A.E. Human papillomaviruses and Epstein-Barr virus interactions in colorectal cancer: a brief review. Pathogens 2020; 9(4): 300, https://doi.org/10.3390/pathogens9040300.

2. Mui U.N., Haley C.T., Tyring S.K. Viral oncology: molecular biology and pathogenesis. J Clin Med 2017; 6(12): 111, https://doi.org/10.3390/jcm6120111.

3. Münz C. Latency and lytic replication in Epstein-Barr virus-associated oncogenesis. Nat Rev Microbiol 2019; 17(11): 691-700, https://doi.org/10.1038/s41579-019-0249-7.

4. Thompson M.P., Kurzrock R. Epstein-Barr virus and cancer. Clin Cancer Res 2004; 10(3): 803-821, https://doi. org/10.1158/1078-0432.ccr-0670-3.

5. Tsang C.M., Tsao S.W. The role of Epstein-Barr virus infection in the pathogenesis of nasopharyngeal carcinoma. Virol Sin 2015; 30(2): 107-121, https://doi.org/10.1007/ s12250-015-3592-5.

6. Chen X.Z., Chen H., Castro F.A., Hu J.K., Brenner H. Epstein-Barr virus infection and gastric cancer: a systematic review. Medicine (Baltimore) 2015; 94(20): e792, https://doi. org/10.1097/md.0000000000000792.

7. Vedham V., Verma M., Mahabir S. Early-life exposures to infectious agents and later cancer development. Cancer Med 2015; 4(12): 1908-1922, https://doi.org/10.1002/cam4.538.

8. Cyprian F.S., Al-Farsi H.F., Vranic S., Akhtar S., Al Moustafa A.E. Epstein-Barr virus and human papillomaviruses interactions and their roles in the initiation of epithelial-mesenchymal transition and cancer progression. Front Oncol 2018; 8: 111, https://doi.org/10.3389/fonc. 2018.00111.

9. Al-Thawadi H., Ghabreau L., Aboulkassim T., Yasmeen A., Vranic S., Batist G., Al Moustafa A.E. Coincidence of Epstein-Barr virus and high-risk human papillomaviruses in cervical cancer of Syrian women. Front Oncol 2018; 8: 250, https://doi.org/10.3389/fonc.2018.00250.

10. She Y., Nong X., Zhang M., Wang M. Epstein-Barr virus infection and oral squamous cell carcinoma risk: a metaanalysis. PLoS One 2017; 12(10): e0186860, https://doi. org/10.1371/journal.pone.0186860.

11. Mozaffari H.R., Ramezani M., Janbakhsh A., Sadeghi M. Malignant salivary gland tumors and Epstein-Barr virus (EBV) infection: a systematic review and meta-analysis. Asian Pac J Cancer Prev 2017; 18(5): 1201-1206, https://doi.org/10.22034/ apjcp.2017.18.5.1201.

12. Al Moustafa A.E., Al-Antary N., Aboulkassim T., Akil N.,
Batist G., Yasmeen A. Co-prevalence of Epstein-Barr virus and high-risk human papillomaviruses in Syrian women with breast cancer. Hum Vaccin Immunother 2016; 12(7): 1936-1939, https://doi.org/10.1080/21645515.2016.1139255.

13. Whitaker N.J., Glenn W.K., Sahrudin A., Orde M.M., Delprado W., Lawson J.S. Human papillomavirus and Epstein Barr virus in prostate cancer: koilocytes indicate potential oncogenic influences of human papillomavirus in prostate cancer. Prostate 2013; 73(3): 236-241, https://doi.org/10.1002/ pros.22562.

14. Shlyakhtunov E.A., Savchenok A.V. Breast cancer and the Epstein-Barr virus. Uspehi molekularnoj onkologii 2015; 2(4): 26-27.

15. Aran V., Victorino A.P., Thuler L.C., Ferreira C.G. Colorectal cancer: epidemiology, disease mechanisms and interventions to reduce onset and mortality. Clin Colorectal Cancer 2016; 15(3): 195-203, https://doi.org/10.1016/j. clcc.2016.02.008.

16. Marley A.R., Nan H. Epidemiology of colorectal cancer. Int J Mol Epidemiol Genet 2016; 7(3): 105-114.

17. Polyakova A.S., Bakradze M.D., Dzhivanshiryan G.V., Tatochenko V.K. Current view of the Epstein-Barr virus infection. Farmateka 2019; 26(10): 27-34, https://doi.org/10. 18565/pharmateca.2019.10.27-34.

18. Murata T., Tsurumi T. Switching of EBV cycles between latent and lytic states. Rev Med Virol 2014; 24(3): 142-153, https://doi.org/10.1002/rmv.1780.

19. Rickinson A. Epstein-Barr virus. Virus Res 2002; 82(1-2): 109-113, https://doi.org/10.1016/s0168-1702(01)00436-1.

20. Skalsky R.L., Cullen B.R. EBV noncoding RNAs. Curr Top Microbiol Immunol 2015; 391: 181-217, https://doi. org/10.1007/978-3-319-22834-1_6.

21. Thorley-Lawson D.A. EBV persistence - introducing the virus. Curr Top Microbiol Immunol 2015; 390(Pt 1): 151209, https://doi.org/10.1007/978-3-319-22822-8_8.

22. Young L.S., Yap L.F., Murray P.G. Epstein-Barr virus: more than 50 years old and still providing surprises. Nat Rev Cancer 2016; 16(12): 789-802, https://doi.org/10.1038/ nrc.2016.92.

23. Babcock G.J., Hochberg D., Thorley-Lawson A.D. The expression pattern of Epstein-Barr virus latent genes in vivo is dependent upon the differentiation stage of the infected $B$ cell. Immunity 2000; 13(4): 497-506, https://doi.org/10.1016/s10747613(00)00049-2.

24. Hartung A., Makarewicz O., Egerer R., Karrasch M., Klink A., Sauerbrei A., Kentouche K., Pletz M.W. EBV miRNA expression profiles in different infection stages: a prospective cohort study. PLoS One 2019; 14(2): e0212027, https://doi. org/10.1371/journal.pone.0212027.

25. Kurth J., Spieker T., Wustrow J., Strickler G.J., Hansmann L.M., Rajewsky K., Küppers R. EBV-infected $B$ cells in infectious mononucleosis: viral strategies for spreading in the B cell compartment and establishing latency. Immunity 2000; 13(4): 485-495, https://doi.org/10.1016/ s1074-7613(00)00048-0.

26. Hochberg D., Middeldorp J.M., Catalina M., Sullivan J.L., Luzuriaga K., Thorley-Lawson D.A. Demonstration of the Burkitt's lymphoma Epstein-Barr virus phenotype in dividing latently infected memory cells in vivo. Proc Natl Acad Sci U S A 2004; 101(1): 239-244, https://doi.org/10.1073/pnas. 2237267100 .

27. Balfour H.H. Jr., Sifakis F., Sliman J.A., Knight J.A., Schmeling D.O., Thomas W. Age-specific prevalence of 
Epstein-Barr virus infection among individuals aged 6-19 years in the United States and factors affecting its acquisition. J Infect Dis 2013; 208(8): 1286-1293, https://doi.org/10.1093/ infdis/jit321.

28. Tsurumi T., Fujita M., Kudoh A. Latent and lytic EpsteinBarr virus replication strategies. Rev Med Virol 2005; 15(1): 3-15, https://doi.org/10.1002/rmv.441.

29. Buettner M., Lang A., Tudor C.S., Meyer B., Cruchley A., Barros M.H.M., Farrell P.J., Jäck H.M., Schuh W., Niedobitek G. Lytic Epstein-Barr virus infection in epithelial cells but not in B-lymphocytes is dependent on Blimp1. J Gen Virol 2012; 93(Pt 5): 1059-1064, https://doi.org/10.1099/ vir.0.038661-0.

30. Frappier L. Ebna1. Curr Top Microbiol Immunol 2015; 391: 3-34, https://doi.org/10.1007/978-3-319-22834-1_1.

31. Bedri S., Sultan A.A., Alkhalaf M., Al Moustafa A.E., Vranic S. Epstein-Barr virus (EBV) status in colorectal cancer: a mini review. Hum Vaccin Immunother 2019; 15(3): 603-610, https://doi.org/10.1080/21645515.2018.1543525.

32. Tsai C.Y., Liu Y.Y., Liu K.H., Hsu J.T., Chen T.C., Chiu C.T., Yeh T.S. Comprehensive profiling of virus microRNAs of Epstein-Barr virus-associated gastric carcinoma: highlighting the interactions of ebv-Bart9 and host tumor cells. J Gastroenterol Hepatol 2017; 32(1): 82-91, https://doi.org/10.1111/jgh.13432.

33. Ignatova E.O., Seryak D.A., Fedyanin M.Yu., Tryakin A.A., Pokataev I.A., Menshikova S.F., Vakhabova Yu.V., Karbyshev M.S., Smirnova K.V., Tulyandin S.A. Molecular portrait of stomach cancer associated with the Epstein-Barr virus. Uspehi molekularnoj onkologii 2020; 7(3): 27-36, https:// doi.org/10.17650/2313-805x-2020-7-3-27-36.

34. Malki M.I., Gupta I., Fernandes Q., Aboulkassim T., Yasmeen A., Vranic S., Al Moustafa A.E., Al-Thawadi H.A. Co-presence of Epstein-Barr virus and high-risk human papillomaviruses in Syrian colorectal cancer samples. Hum Vaccin Immunother 2020; 16(10): 2403-2407, https://doi.org/ 10.1080/21645515.2020.1726680.

35. Gupta I., Al Farsi H., Jabeen A., Skenderi F., Al-Thawadi H., AlAhmad Y.M., Al Moustafa A.E., Vranic S. High-risk human papillomaviruses and Epstein-Barr virus in colorectal cancer and their association with clinicopathological status. Pathogens 2020; 9(6): 452, https://doi.org/10.3390/ pathogens9060452.

36. Sarvari J., Mahmoudvand S., Pirbonyeh N., Safaei A., Hosseini S.Y. The very low frequency of Epstein-Barr JC and BK viruses DNA in colorectal cancer tissues in Shiraz, Southwest Iran. Pol J Microbiol 2018; 67(1): 73-79, https://doi. org/10.5604/01.3001.0011.6146.

37. Al-Antary N., Farghaly H., Aboulkassim T., Yasmeen A., Akil N., Al Moustafa A.E. Epstein-Barr virus and its association with Fascin expression in colorectal cancers in the Syrian population: a tissue microarray study. Hum Vaccin Immunother 2017; 13(7): 1573-1578, https://doi.org/10.1080/ 21645515.2017.1302046.

38. Mehrabani-Khasraghi S., Ameli M., Khalily F. Demonstration of herpes simplex virus, cytomegalovirus, and Epstein-Barr virus in colorectal cancer. Iran Biomed J 2016; 20(5): 302-306, https://doi.org/10.22045/ibj.2016.08.

39. Tafvizi F., Fard Z.T., Assareh R. Epstein-Barr virus DNA in colorectal carcinoma in Iranian patients. Pol J Pathol 2015; 66(2): 154-160, https://doi.org/10.5114/ pjp.2015.53012.

40. Sole C.V., Calvo F.A., Ferrer C., Alvarez E.,
Carreras J.L., Ochoa E. Human cytomegalovirus and EpsteinBarr virus infection impact on ${ }^{18} \mathrm{~F}-\mathrm{FDG}$ PET/CT SUVmax, CT volumetric and KRAS-based parameters of patients with locally advanced rectal cancer treated with neoadjuvant therapy. Eur J Nucl Med Mol Imaging 2015; 42(2): 186-196, https://doi. org/10.1007/s00259-014-2910-8.

41. Guan X., Yi Y., Huang Y., Hu Y., Li X., Wang X., Fan H., Wang G., Wang D. Revealing potential molecular targets bridging colitis and colorectal cancer based on multidimensional integration strategy. Oncotarget 2015; 6(35): 37600-37612, https://doi.org/10.18632/oncotarget.6067.

42. Fiorina L., Ricotti M., Vanoli A., Luinetti O., Dallera E., Riboni R., Paolucci S., Brugnatelli S., Paulli M., Pedrazzoli P., Baldanti F., Perfetti V. Systematic analysis of human oncogenic viruses in colon cancer revealed EBV latency in lymphoid infiltrates. Infect Agent Cancer 2014; 9: 18, https://doi. org/10.1186/1750-9378-9-18.

43. Salyakina D., Tsinoremas N.F. Viral expression associated with gastrointestinal adenocarcinomas in TCGA high-throughput sequencing data. Hum Genomics 2013; 7(1): 23, https://doi.org/10.1186/1479-7364-7-23.

44. Khoury J.D., Tannir N.M., Williams M.D., Chen Y., Yao H., Zhang J., Thompson E.J.; TCGA Network, MericBernstam F., Medeiros L.J., Weinstein J.N., Su X. Landscape of DNA virus associations across human malignant cancers: analysis of 3,775 cases using RNA-Seq. J Virol 2013; 87(16): 8916-8926, https://doi.org/10.1128/jvi.00340-13.

45. Delaney D., Chetty R. Lymphoepithelioma-like carcinoma of the colon. Int J Clin Exp Pathol 2012; 5(1): 105-109.

46. Karpinski P., Myszka A., Ramsey D., Kielan W., Sasiadek M.M. Detection of viral DNA sequences in sporadic colorectal cancers in relation to $\mathrm{CpG}$ island methylation and methylator phenotype. Tumour Biol 2011; 32(4): 653-659, https://doi.org/10.1007/s13277-011-0165-6.

47. Chang H., Chuang W.Y., Shih L.Y., Tang T.C. Collision in the colon: concurrent adenocarcinoma and diffuse large B-cell lymphoma in the same tumour. Acta Clin Belg 2011; 66(4): 302-304.

48. Park J.M., Choi M.G., Kim S.W., Chung I.S., Yang C.W., Kim Y.S., Jung C.K., Lee K.Y., Kang J.H. Increased incidence of colorectal malignancies in renal transplant recipients: a case control study. Am J Transplant 2010; 10(9): 2043-2050, https:// doi.org/10.1111/j.1600-6143.2010.03231.x.

49. Nishigami T., Kataoka T.R., Torii I., Sato A., Tamura K., Hirano H., Hida N., Ikeuchi H., Tsujimura T. Concomitant adenocarcinoma and colonic non-Hodgkin's lymphoma in a patient with ulcerative colitis: a case report and molecular analysis. Pathol Res Pract 2010; 206(12): 846-850, https://doi. org/10.1016/j.prp.2010.07.007.

50. Militello V., Trevisan M., Squarzon L., Biasolo M.A., Rugge M., Militello C., Palù G., Barzon L. Investigation on the presence of polyomavirus, herpesvirus, and papillomavirus sequences in colorectal neoplasms and their association with cancer. Int J Cancer 2009; 124(10): 2501-2503, https://doi. org/10.1002/ijc.24224.

51. Song L.B., Zhang X., Zhang C.Q., Zhang Y., Pan Z.Z., Liao W.T., Li M.Z., Zeng M.S. Infection of Epstein-Barr virus in colorectal cancer in Chinese. Ai Zheng 2006; 25(11): 13561360.

52. Wong N.A.C.S., Herbst H., Herrmann K., Kirchner T., Krajewski A.S., Moorghen M., Niedobitek F., Rooney N., Shepherd N.A., Niedobitek G. Epstein-Barr virus infection in colorectal neoplasms associated with inflammatory bowel 
disease: detection of the virus in lymphomas but not in adenocarcinomas. J Pathol 2003; 201(2): 312-318, https://doi. org/10.1002/path.1442.

53. Grinstein S., Preciado M.V., Gattuso P., Chabay P.A., Warren W.H., De Matteo E., Gould V.E. Demonstration of Epstein-Barr virus in carcinomas of various sites. Cancer Res 2002; 62(17): 4876-4878.

54. Kon S., Kasai K., Tsuzuki N., Nishibe M., Kitagawa T., Nishibe T., Sato N. Lymphoepithelioma-like carcinoma of rectum: possible relation with EBV. Pathol Res Pract 2001; 197(8): 577-582, https://doi.org/10.1078/0344-0338-00130.

55. Kijima Y., Hokita S., Takao S., Baba M., Natsugoe S., Yoshinaka H., Aridome K., Otsuji T., Itoh T., Tokunaga M., Eizuru Y., Aikou T. Epstein-Barr virus involvement is mainly restricted to lymphoepithelial type of gastric carcinoma among various epithelial neoplasms. J Med Virol 2001; 64(4): 513518, https://doi.org/10.1002/jmv.1079.

56. Cho Y.J., Chang M.S., Park S.H., Kim H.S., Kim W.H. In situ hybridization of Epstein-Barr virus in tumor cells and tumor-infiltrating lymphocytes of the gastrointestinal tract. Hum Pathol 2001; 32(3): 297-301, https://doi.org/10.1053/ hupa.2001.22766.

57. Samaha S., Tawfik O., Horvat R., Bhatia P. Lymphoepithelioma-like carcinoma of the colon: report of a case with histologic, immunohistochemical, and molecular studies for Epstein-Barr virus. Dis Colon Rectum 1998; 41(7): 925-928, https://doi.org/10.1007/bf02235379.

58. Vilor M., Tsutsumi Y. Localization of Epstein-Barr virus genome in lymphoid cells in poorly differentiated adenocarcinoma with lymphoid stroma of the colon. Pathol Int 1995; 45(9): 695-697, https://doi.org/10.1111/j. 1440-1827.1995.tb03524.x.

59. Yuen S.T., Chung L.P., Leung S.Y., Luk I.S., Chan S.Y., Ho J. In situ detection of Epstein-Barr virus in gastric and colorectal adenocarcinomas. Am J Surg Pathol 1994; 18(11): 1158-1163, https://doi.org/10.1097/00000478-199411000-00010.

60. Boguszaková L., Hirsch I., Brichácek B., Faltýn J., Fric P., Dvoráková H., Vonka V. Absence of cytomegalovirus, Epstein-Barr virus, and papillomavirus DNA from adenoma and adenocarcinoma of the colon. Acta Virol 1988; 32(4): 303-308.

61. Nonoyama M., Kawai Y., Huang C.H., Pagano J.S., Hirshaut Y., Levine P.H. Epstein-Barr virus DNA in Hodgkin's disease, American Burkitt's lymphoma, and other human tumors. Cancer Res 1974; 34(5): 1228-1231.

62. Cajuso T., Hänninen U.A., Kondelin J., Gylfe A.E., Tanskanen T., Katainen R., Pitkänen E., Ristolainen H., Kaasinen E., Taipale M., Taipale J., Böhm J., RenkonenSinisalo L., Mecklin J.P., Järvinen H., Tuupanen S., Kilpivaara O., Vahteristo $P$. Exome sequencing reveals frequent inactivating mutations in ARID1A, ARID1B, ARID2 and ARID4A in microsatellite unstable colorectal cancer. Int J Cancer 2014; 135(3): 611-623, https://doi.org/10.1002/ijc.28705.

63. Ling C., Wang L., Wang Z., Xu L., Sun L., Yang H., Li W.D., Wang K. A pathway-centric survey of somatic mutations in Chinese patients with colorectal carcinomas. PLoS One 2015; 10(1): e0116753, https://doi.org/10.1371/ journal.pone.0116753.

64. Kim Y.S., Jeong H., Choi J.W., Oh H.E., Lee J.H. Unique characteristics of ARID1A mutation and protein level in gastric and colorectal cancer: a meta-analysis. Saudi J Gastroenterol 2017; 23(5): 268-274, https://doi.org/10.4103/ sjg.sjg_184_17.
65. Hay E.D. An overview of epithelio-mesenchymal transformation. Acta Anat (Basel) 1995; 154(1): 8-20, https:// doi.org/10.1159/000147748.

66. Al Moustafa A.E., Achkhar A., Yasmeen A. EGFreceptor signaling and epithelial-mesenchymal transition in human carcinomas. Front Biosci (Schol Ed) 2012; 4: 671-684, https://doi.org/10.2741/s292.

67. Tsai J.H., Yang J. Epithelial-mesenchymal plasticity in carcinoma metastasis. Genes Dev 2013; 27(20): 2192-2206, https://doi.org/10.1101/gad.225334.113.

68. Thiery J.P., Acloque H., Huang R.Y., Nieto M.A. Epithelial-mesenchymal transitions in development and disease. Cell 2009; 139(5): 871-890, https://doi.org/10.1016/j. cell.2009.11.007.

69. Scanlon C.S., Van Tubergen E.A., Inglehart R.C., D'Silva N.J. Biomarkers of epithelial-mesenchymal transition in squamous cell carcinoma. J Dent Res 2013; 92(2): 114-121, https://doi.org/10.1177/0022034512467352.

70. Tam W.L., Weinberg R.A. The epigenetics of epithelialmesenchymal plasticity in cancer. Nat Med 2013; 19(11): 1438-1449, https://doi.org/10.1038/nm.3336.

71. Chen X., Bode A.M., Dong Z., Cao Y. The epithelialmesenchymal transition (EMT) is regulated by oncoviruses in cancer. FASEB J 2016; 30(9): 3001-3010, https://doi. org/10.1096/fj.201600388r.

72. Lin Z., Wan X., Jiang R., Deng L., Gao Y., Tang J., Yang Y., Zhao W., Yan X., Yao K., Sun B., Chen Y. EpsteinBarr virus-encoded latent membrane protein $2 \mathrm{~A}$ promotes the epithelial-mesenchymal transition in nasopharyngeal carcinoma via metastatic tumor antigen 1 and mechanistic target of rapamycin signaling induction. J Virol 2014; 88(20): 11872-11885, https://doi.org/10.1128/jvi.01867-14.

73. Gaur N., Gandhi J., Robertson E.S., Verma S.C., Kaul R. Epstein-Barr virus latent antigens EBNA3C and EBNA1 modulate epithelial to mesenchymal transition of cancer cells associated with tumor metastasis. Tumour Biol 2015; 36(4): 3051-3060, https://doi.org/10.1007/s13277-014-2941-6.

74. Cai L.M., Lyu X.M., Luo W.R., Cui X.F., Ye Y.F., Yuan C.C., Peng Q.X., Wu D.H., Liu T.F., Wang E., Marincola F.M., Yao K.T., Fang W.Y., Cai H.B., Li X. EBVmiR-BART7-3p promotes the EMT and metastasis of nasopharyngeal carcinoma cells by suppressing the tumor suppressor PTEN. Oncogene 2015; 34(17): 2156-2166, https://doi.org/10.1038/onc.2014.341.

75. He B., Li W., Wu Y., Wei F., Gong Z., Bo H., Wang Y., Li X., Xiang B., Guo C., Liao Q., Chen P., Zu X., Zhou M., Ma J., Li X., Li Y., Li G., Xiong W., Zeng Z. Epstein-Barr virus-encoded miR-BART6-3p inhibits cancer cell metastasis and invasion by targeting long non-coding RNA LOC553103. Cell Death Dis 2016; 7(9): e2353, https://doi.org/10.1038/cddis.2016.253.

76. Zuo L.L., Zhang J., Liu L.Z., Zhou Q., Du S.J., Xin S.Y., Ning Z.P., Yang J., Yu H.B., Yue W.X., Wang J., Zhu F.X., Li G.Y., Lu J.H. Cadherin 6 is activated by Epstein-Barr virus LMP1 to mediate EMT and metastasis as an interplay node of multiple pathways in nasopharyngeal carcinoma. Oncogenesis 2017; 6(12): 402, https://doi.org/10.1038/s41389-017-0005-7.

77. Mjelle R., Sjursen W., Thommesen L., Sætrom P., Hofsli E. Small RNA expression from viruses, bacteria and human miRNAs in colon cancer tissue and its association with microsatellite instability and tumor location. BMC Cancer 2019; 19(1): 161, https://doi.org/10.1186/s12885-019-5330-0.

78. Rizzo A.G., Orlando A., Gallo E., Bisanti A., Sferrazza S., Montalbano L.M., Macaluso F.S., Cottone M. Is 
Epstein-Barr virus infection associated with the pathogenesis of microscopic colitis? J Clin Virol 2017; 97: 1-3, https://doi. org/10.1016/j.jcv.2017.10.009.

79. Nissen L.H.C., Nagtegaal I.D., de Jong D.J., Kievit W., Derikx L.A.A.P., Groenen P.J.T.A., van Krieken J.H.M., Hoentjen F. Epstein-Barr virus in inflammatory bowel disease: the spectrum of intestinal lymphoproliferative disorders. J Crohns Colitis 2015; 9(5): 398-403, https://doi.org/10.1093/ ecco-jcc/jjv040.
80. Ryan J.L., Shen Y.J., Morgan D.R., Thorne L.B., Kenney S.C., Dominguez R.L., Gulley M.L. Epstein-Barr virus infection is common in inflamed gastrointestinal mucosa. Dig Dis Sci 2012; 57(7): 1887-1898, https://doi.org/10.1007/ s10620-012-2116-5.

81. Spieker T., Herbst H. Distribution and phenotype of Epstein-Barr virus-infected cells in inflammatory bowel disease. Am J Pathol 2000; 157(1): 51-57, https://doi. org/10.1016/s0002-9440(10)64516-6. 